\title{
SEEDS OF ELEPHANT APPLE (DILLENIA INDICA L.) RESPONSE TO SOME PRE-GERMINATION TREATMENTS
}

\author{
S.M. Shahin ; Amal S. El-Fouly ${ }^{* *}$ and Azza M. Abdel-Moniem ${ }^{* *}$ \\ * Botanical Gardens Res. Dept., Hort. Res. Inst., ARC, Giza, Egypt. \\ ** Ornamental Plants and Landscape Gardening Res. Dept., Hort. Res. Inst., ARC, Giza, Egypt.
}

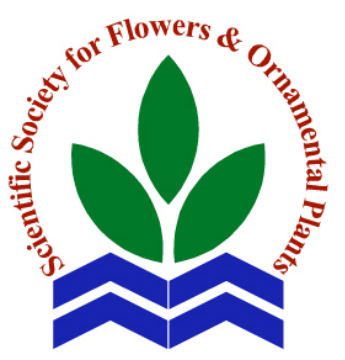

ABSTRACT: This experiment was consummated under shade at the nursery of Hort. Res. Inst., ARC, Giza, Egypt during 2013 and 2014 seasons to explore the effect of some pre-sowing treatments, viz. control (untreated seeds), seeds without mucilage, soaking in tap water for $24,48,72 \mathrm{~h}$ under ambient conditions, soaking in hot water (60$70^{\circ} \mathrm{C}$ ) for $24 \mathrm{~h}$, soaking in absolute ethanol $(97 \%)$ for either 12 or $24 \mathrm{~h}$ and soaking in concentrated sulfuric acid (98.5\%) for $3 \mathrm{~min}$ on germination measurements of Elephant apple (Dillenia indica L.) seeds and growth of the produced seedlings.

The obtained results have shown that seeds of control and those soaked in either hot water or ethanol for $24 \mathrm{~h}$ failed to germinate, while seeds without mucilage and those soaked in ethanol for $12 \mathrm{~h}$ gave the least germination percentage in the two seasons. The other treatments, however significantly improved germination $\%$, with the superiority of soaking in concentrated $\mathrm{H}_{2} \mathrm{SO}_{4}$ for 3 min treatment, which elevated such parameter to $100 \%$ in both seasons. Besides, germination \% was

Scientific J. Flowers \& found to progressively increase with elongating soaking period in tap Ornamental Plants, 2(1):39-50 (2015). water to reach $100 \%$ in the first season and $83.33 \%$ in the second one by the longest soaking period $(72 \mathrm{~h})$. The germination velocity and mean germination rate were accelerated and the indices of germination

Received:

$3 / 12 / 2014$ rate and vigour, seeds viability and plumule length were significantly improved by some treatments used in this trial, but the prevalence was

Revised by: also for acid treatment which followed by soaking in tap water for $72 \mathrm{~h}$ Prof. Dr. A.Z. Sarhan, Cairo Univ.

Prof. Dr. M.M. Farahat, Agric. \& Biol. Res. Div., NRC. treatment. Similarly, were those result of seedling growth traits and leaf content of chlorophyll a, b, carotenoids, total soluble sugars, indoles and phenols, as the soaking in concentrated $\mathrm{H}_{2} \mathrm{SO}_{4}$ for $3 \mathrm{~min}$ treatment scored the best growth of the seedling and the highest content of the various constituents which was accompanied with the least content of total phenols. Also, soaking in tap water for $72 \mathrm{~h}$ occupied second rank.

So, it advised to soak Elephant apple (Dillenia indica L.) tree seeds either in concentrated sulfuric acid (98.5\%) for 3 min or in tap water for $72 \mathrm{~h}$ to obtain the best germination and quality of seedlings.

Key words: Elephant apple (Dillenia indica L.) tree, seed germination, pre-sowing treatments, seedling growth.

\section{INTRODUCTION}

Dillenia indica L., Elephant apple or Chulta (Fam. Dilleniaceae) is an evergreen spreading tree, grown in gardens for its attractive white fragrant flowers, toothed leaves and fleshy globose edible fruits (Huxley et al., 1992). It is an ethnomedicinally important plant used for the treatment of severe disease like cancer and diarrhe. The fruit extract has shown significant anit-leukemic activity in human 


\section{S.M. Shahin et al.}

leukemic cell lines. The fruits possess tonic and laxative properties and is used for abdominal pains. The antioxidant effect of such tree is mainly due to phenolic compounds such as flavonoids, phenolic acids, tannins and phenolic diterpens. Phenolic compounds inhibit free radicals in the body which are responsible for oxidative damages (Gogoi et al., 2012). These medicinal uses were documented by Parvin et al., (2009), Rahaman et al., (2011), Alam et al., (2011) and Singha et al., (2013) who suggested that the crude extract of $D$. indica plant contains some compounds which have antimicrobial activity, more potent antioxidant activity and $\alpha$-glucosidase inhibitory activity.

Dillenia indica usually propagates by seeds borne within large indehiscent fruits. When extracted fresh, seeds are glued together by the sticky mucilage on the seedcoat. This sticky mucilage does not promote or inhibit germination, but it does restrict the inflow of water into seeds during the initial stages of imbibition. The embryo of $D$. indica is under developed. Thus, the seeds have morphological dormancy (Thapliyal et al., 2008). The mucilaginous layer in Dillenia species acts as a physical barrier and prevents germination by reducing diffusion of water and oxygen to the inner tissue of the seed (Panigrahi, 1986). In this regard, Thapliyal et al., (2008) found that there were no significant effects of mucilage on either germination $\%$ or mean germination time (MGT) of $D$. indica seeds. Seeds with intact mucilage and without mucilage germinated to 92 and $97 \%$, respectively, and MGT was 28 and 26 days, respectively.

There is a limited body of information in the literature regarding breaking the physical or morphological dormancy of $D$. indica seeds, but the following observations may be valied in this concern. Alamgir and Hossain (2005) reported that immersing seeds of Albizia saman in tap water for $24 \mathrm{~h}$ may be recommended for maximum germination and initial vigorous seedlings growth in the nursery. Bhardwaj et al. (2007) elicited that Albizia lebbeck seeds pre-treated with concentrated $\mathrm{H}_{2} \mathrm{SO}_{4}$ for 8 min followed by soaking in tap water for $3 \mathrm{~h}$ gave significant germination and better seedling growth under both laboratory and nursery conditions. On Acacia mangium, Bahar (2011) revealed that hot water soaking for 24 h or $\mathrm{H}_{2} \mathrm{SO}_{4}$ for 15 min soaking enhanced germination of seeds to more than $92 \%$. Like results were also obtained by Singh and Dhillon (2007) on Acacia nilotica, Prosopis cineraria and Lucaena leucocephala, Azad et al. (2010) on Albizia richardiana and Lagerstroemia speciosa, Azad et al. (2012) on Albizia procera, Khan (2013) on Cassia auriculata and Cassia tora, Pivetta et al. (2013) on Carnauba palm and Shahin et al. (2014) whom observed that soaking the depulped seeds of triangle palm in concentrated $\mathrm{H}_{2} \mathrm{SO}_{4}$ for $3 \mathrm{~h}$ gave the best germination percentage and velocity, higher means of vigour index, seed viability and plumule length, best growth of the resulted seedlings, as well as higher content of pigments, soluble sugars, indoles and phenols in the leaves.

This study aims to detect the most appropriate treatments for enhancing seed germination of Elephant apple tropical tree along with getting high quality seedlings.

\section{MATERIALS AND METHODS}

This trial was carried out at the nursery of Hort. Res. Inst., ARC, Giza, Egypt throughout the consecutive seasons of 2013 and 2014 in order to improve germination of Elephant apple tree seeds and quality of the produced seedlings using some pre-sowing treatments.

Thus, the round fruits of Elephant apple (Dillenia indica L.) tree were collected from Giza Zoo on March, $15^{\text {th }}$ for each season, then seeds were extracted from carples immediately on the second day (each fruit consists of 16-20 carples, each containing 5 seeds or more, so each fruit gives around 80100 seeds). The seeds were left exposed to air $24 \mathrm{~h}$ until been dried, then were preserved 
in paper bag till the time of planting (Figs. 1, 2 and 3$)$.

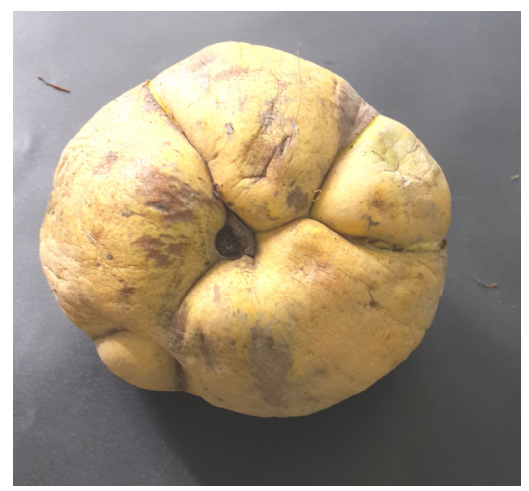

Fig. 1. The intact fruit.

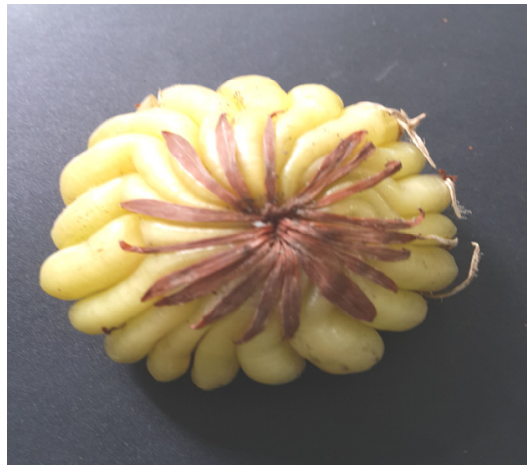

Fig. 2. The carples after removing pseudocarpes.

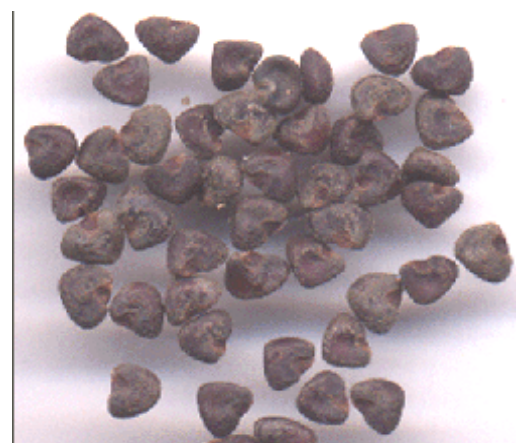

Fig. 3. The seeds.

On April, $1^{\text {st }}$, the seeds were sterilized with sodium hydrochloride solution $(10 \%)$ for 10 minutes, then rinsed several times with sterile distilled water and directly subjected to some pre-sowing treatments as follows:

1- Untreated seeds, referred to as control.

2- Seeds without mucilage, where mucilage was scraped off completely from the surface of seeds by rubbing them gently on a fine wire-net mesh for several minutes.
3- Soaking in tap water for 24,48 and 72 hours at room temperatures (about $33{ }^{\circ} \mathrm{C}$ for the two seasons).

4- Soaking in hot water $\left(60-70{ }^{\circ} \mathrm{C}\right)$ for 24 hours.

5- Soaking in absolute ethanol (97\%) for 12 and 24 hours.

6- Soaking in concentrated sulfuric acid $(98.5 \%)$ for 3 minutes.

The treated seeds and those of control were sown immediately after treatment in 16-cm-diameter pots (10 seeds/pot) filled with about $1.8 \mathrm{~kg}$ of sand and clay mixture (1:1, by volume). Some physical and chemical properties of the sand and clay used in both seasons are presented in Table (1).

The layout of the experiment in the two seasons was a completely randomized design, replicated thrice, as each pot contained 10 seeds exemplifies one replicate (Mead et al., 1993). Clearly visible plumule protrusion was used as a criterion for germination. All agricultural practices needed for care the seeds were done. Number of germinated seeds was recorded every day and plumule length $(\mathrm{cm})$ was measured after a week from emergence.

The experiment was terminated 120 days after seed sowing (on July, $30^{\text {th }}$ for each season), the time at which no additional seeds had germinated for 2 weeks. At that time, the following germination characteristics were calculated:

1- Germination percentage (G. \%) from the following equation:

G. $\%=$ No. germinated seeds / Total No. sown seeds $\times 100$

2- Germination velocity (G.V.) in days, which equal average number of days from sowing till emergence of the final plumule .

3- Mean germination rate (M.G.R.) in days $=$ mean number of days till $50 \%$ germination (Odetola, 1987). 
Table 1. The physical and chemical analysis of the used sand and clay during 2013 and 2014 seasons.

\begin{tabular}{|c|c|c|c|c|c|c|c|c|c|c|c|c|c|c|}
\hline \multirow[b]{2}{*}{ Soil type } & \multicolumn{4}{|c|}{ Particle size distribution $(\%)$} & \multirow[b]{2}{*}{ S.P. } & \multirow{2}{*}{$\begin{array}{c}\text { E.C. } \\
(\mathrm{dS} / \mathrm{m})\end{array}$} & \multirow{2}{*}{ pH } & \multicolumn{4}{|c|}{ Cations (meq/l) } & \multicolumn{3}{|c|}{ Anions (mq/l) } \\
\hline & $\begin{array}{c}\text { Coarse } \\
\text { sand }\end{array}$ & $\begin{array}{l}\text { Fine } \\
\text { sand }\end{array}$ & Silt & Clay & & & & $\mathrm{Ca}^{++}$ & $\mathbf{M g}^{++}$ & $\mathrm{Na}^{+}$ & $\mathbf{K}^{+}$ & $\mathrm{HCO}_{3}{ }_{3}^{-}$ & $\mathrm{Cl}^{-}$ & $\mathrm{SO}_{4}^{-}$ \\
\hline Sand & 89.03 & 2.05 & 0.40 & 5.52 & 25.00 & 7.75 & 6.73 & 11.11 & 16.08 & 58.20 & 10.34 & 0.96 & 58.99 & 25.78 \\
\hline Clay & 7.54 & 22.28 & 30.55 & 39.63 & 40.00 & 7.80 & 1.97 & 4.96 & 3.10 & 10.64 & 1.09 & 1.02 & 11.32 & 7.45 \\
\hline
\end{tabular}

4- Germination rate index (G.R.I.), which calculated from Bartled equation indicated by Hartmann and Kester (1983). GRI $=\mathrm{A}+(\mathrm{A}+\mathrm{B})+(\mathrm{A}+\mathrm{B}+$ $\mathrm{C})+\ldots / \mathrm{N}(\mathrm{A}+\mathrm{B}+\mathrm{C} \ldots .$.$) .$

- Where: A, B, C, .... etc. are number of germinated seeds counted at different times, and $\mathrm{N}$ is number of times at which the germinated seeds were counted.

5- Vigour index (V.I.) $=$ G. $\% \times$ mean length of plumule (Selvaraju and Selvaraj, 1994)

6- Seed viability $(\mathrm{SV})=$ number of survived seedlings in each treatment after excluding the deteriorated and dead ones (Odetola, 1987).

In addition, data of the resulted seedlings from the different treatments was recorded as follows: seedling length $(\mathrm{cm})$, number of leaves/seedling, root length $(\mathrm{cm})$, number of roots/seedling, as well as fresh and dry weights of top growth and roots $(\mathrm{g})$.

In fresh leaf samples, photosynthetic pigments (chlorophyll a, b and carotenoids, $\mathrm{mg} / \mathrm{g}$ f.w.) and the percentages of total soluble sugars, indoles and phenols were evaluated according to the methods described by Moran (1982), Dubois et al. (1956), A.O.A.C. (1990) and William et al. (1965), respectively.

Data were then tabulated and statistically analyzed according to program SAS Institute (1994), using Duncan's Multiple Range Test (Duncan, 1955) to elucidating the significancy between the means of the different treatments.

\section{RESULTS AND DISCUSSION}

\section{Effect of pre-sowing treatments on:}

\section{1- Germination characteristics:}

Data in Table (2) exhibit that germination $\%$ reached the maximum by soaking in concentrated $\mathrm{H}_{2} \mathrm{SO}_{4}$ for $3 \mathrm{~min}$ treatment which gave $100 \%$ germination in the two seasons. The soaking in tap water for $72 \mathrm{~h}$ treatment gave $100 \%$ germination in the first season, but in the second one it recorded only $83.33 \%$ germination occuping the second rank after acid treatment. However, germination percent was progressively increased with elongating the period of soaking in tap water, especially in the second season. The least percent of germination was attained by the seeds without mucilage and those soaked in ethanol for either 12 or $24 \mathrm{~h}$. On the other side, seeds of control and of those soaked in hot water for $24 \mathrm{~h}$ failed to germinate in the two seasons, besides the seeds soaked in ethanol for $24 \mathrm{~h}$ in the second one, as these treatments registered zero $\%$ of germination.

The least number of days to either $100 \%$ or $50 \%$ germination in both seasons was also attributed to soaking in concentrated $\mathrm{H}_{2} \mathrm{SO}_{4}$ for 3 min treatment, which was followed by soaking in tap water for $72 \mathrm{~h}$ treatment. The best means of germination rate index (GRI), as a real indication for germination accelerating was also achieved in the two seasons by acid treatment which significantly reduced such parameter to 0.50 in the $1^{\text {st }}$ season and to 0.51 in the $2^{\text {nd }}$ one. Moreover, the highest means of vigour index 
Scientific J. Flowers \& Ornamental Plants, 2(1):39-50 (2015)

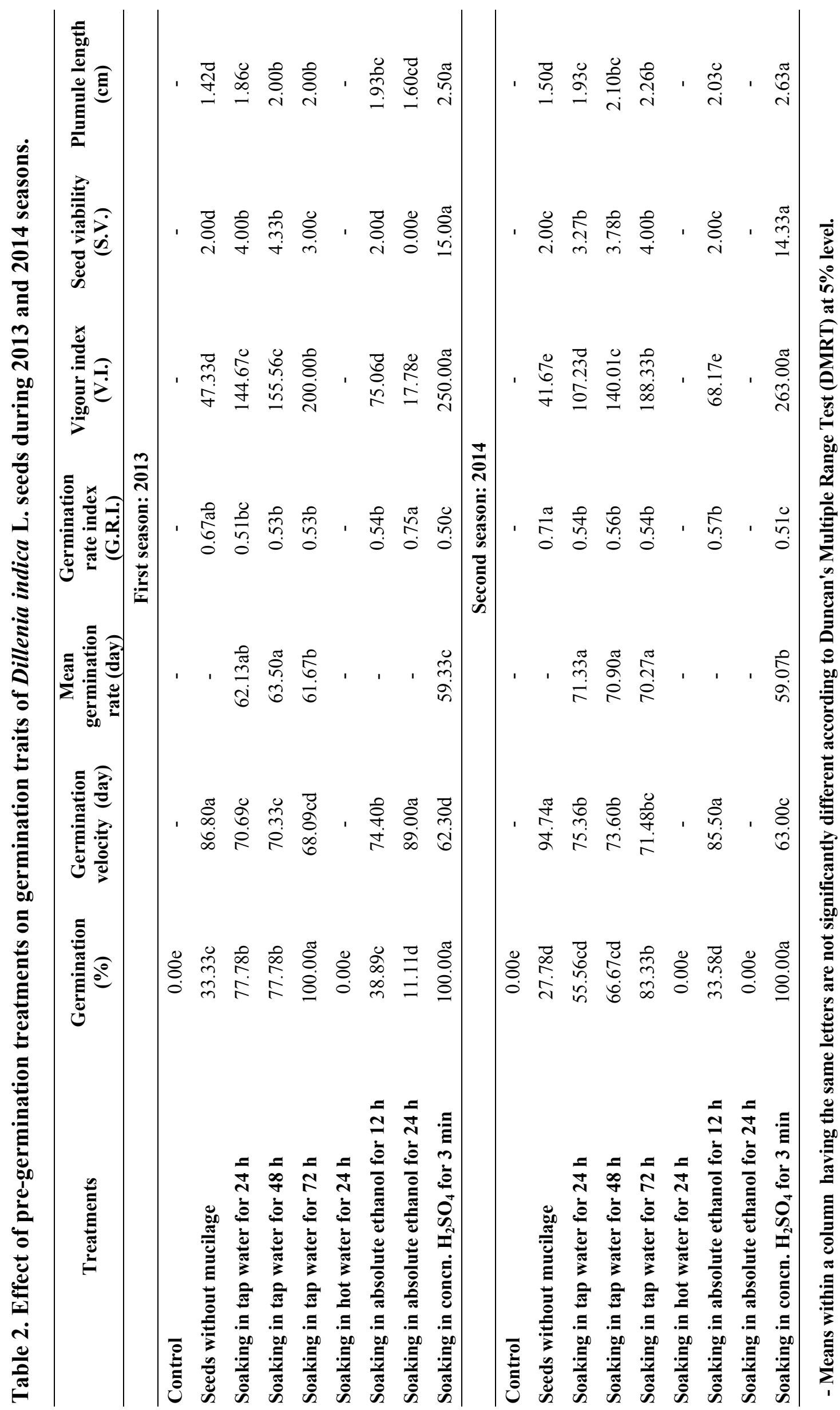




\section{S.M. Shahin et al.}

(V.I.), seed viability (S.V.) and plumule length $(\mathrm{cm})$ were also due to soaking the seeds in concentrated $\mathrm{H}_{2} \mathrm{SO}_{4}$ for $3 \mathrm{~min}$ treatment that gave means suprpassed those of other treatments in both seasons.

Improving germination characters by concentrated sulfuric acid as indicated above may be ascribed to the role of this acid in softening and lightening the seed coats and that consequently permits the ease permeable of water and gasses across the soften coats which finally leads to activating enzymes that decay the stored foods in the endosperm and producing sugars and energy required for growth of the embryo (Bahar, 2011). In this connection, Khan (2013) manifested that 80\% seeds were germinated in Cassia auriculata and $88 \%$ seeds were germinated in Cassia tora after 5 min soaking in concentrated $\mathrm{H}_{2} \mathrm{SO}_{4}$. The previous gains were supported by those declared by Alamgir and Hossain (2005) on Albizia saman, Bhardwaj et al. (2007) on Albizia lebbeck, Pivetta et al. (2013) on Carnauba palm and Shahin et al. (2014) on Triangle palm.

\section{2- Seedling growth characters:}

It can be seen from Tables ( 3 and 4 ) and Fig. (4) that the best growth of seedlings was attained by soaking the seeds in concentrated $\mathrm{H}_{2} \mathrm{SO}_{4}$ for $3 \mathrm{~min}$, as this treatment recorded the longest seedling and root lengths $(\mathrm{cm})$, the highest No. leaves and roots/seedling, as well as the heaviest fresh and dry weights of top growth and roots (g) with significant differences compared to other treatments in the two seasons. Furthermore, soaking in tap water for $72 \mathrm{~h}$ treatment caused a significant increment in the various growth traits of seedlings giving averages closely near to those of the acid treatment with non-significant differences between them in some instances of both seasons. However, the least records of seedling growth criteria were referred to removing mucilage treatment which gave the shortest seedling and root lengths, the least No. leaves and roots/seedling accompanied with the lightest fresh and dry weights of top growth and roots in the two seasons.
Improving vegetative and root growth of seedlings by acid treatment may indicate the role of sulfuric acid on softening the outer seed coats and altering lens structure, consequently permits the seeds to absorb more water and gasses necessary for activating enzymatic systems that induce hydrolysis of the complex food reserves to absorbable forms. Besides, the early germination under this treatment saving more time for the resulted seedlings to grow well, whereas seeds under other treatments are still dormant. Similarly, were those results explored by Singh and Dhillon (2007) on Acacia nilotica, Prosopis cineraria and Lucaena leucocephala, Azad et al. (2010) on Albizia richardiana and Lagerstroemia speciosa and Khan (2013) on Cassia auriculata and Cassia tora.

\section{3- Chemical composition:}

It is clear from data illustrated in Table (5) that chlorophyll a, b and carotenoids content (mg/g f.w.), as well as the percentages of total soluble sugars and total indoles were improved in the leaves of seedlings raised from seeds soaked in tap water (for any period), ethanol for $12 \mathrm{~h}$ or concentrated $\mathrm{H}_{2} \mathrm{SO}_{4}$ for $3 \mathrm{~min}$ compared to those raised from seeds without mucilage, with the dominance of soaking in concentrated sulfuric acid for $3 \mathrm{~min}$ treatment which gave the utmost high content of the above named constituents. In addition, content of the previous components was progressively increased with prolonging the period of soaking in tap water. The opposite was the right concerning the content of total phenols (\%) which markedly decreased in response to soaking in tap water (a progressive decrement in such parameter was attained with protraction of soaking period), ethanol for $12 \mathrm{~h}$ and in concentrated $\mathrm{H}_{2} \mathrm{SO}_{4}$ for 3 min treatment that reduced content of such constituent to the least value (0.0022 against $0.011 \%$ for seeds free of mucilage).

This may be explain why this treatment scored the highest and earliest germination, and may indicate the inhibitory effect of phenols which modify the activity of IAA- 


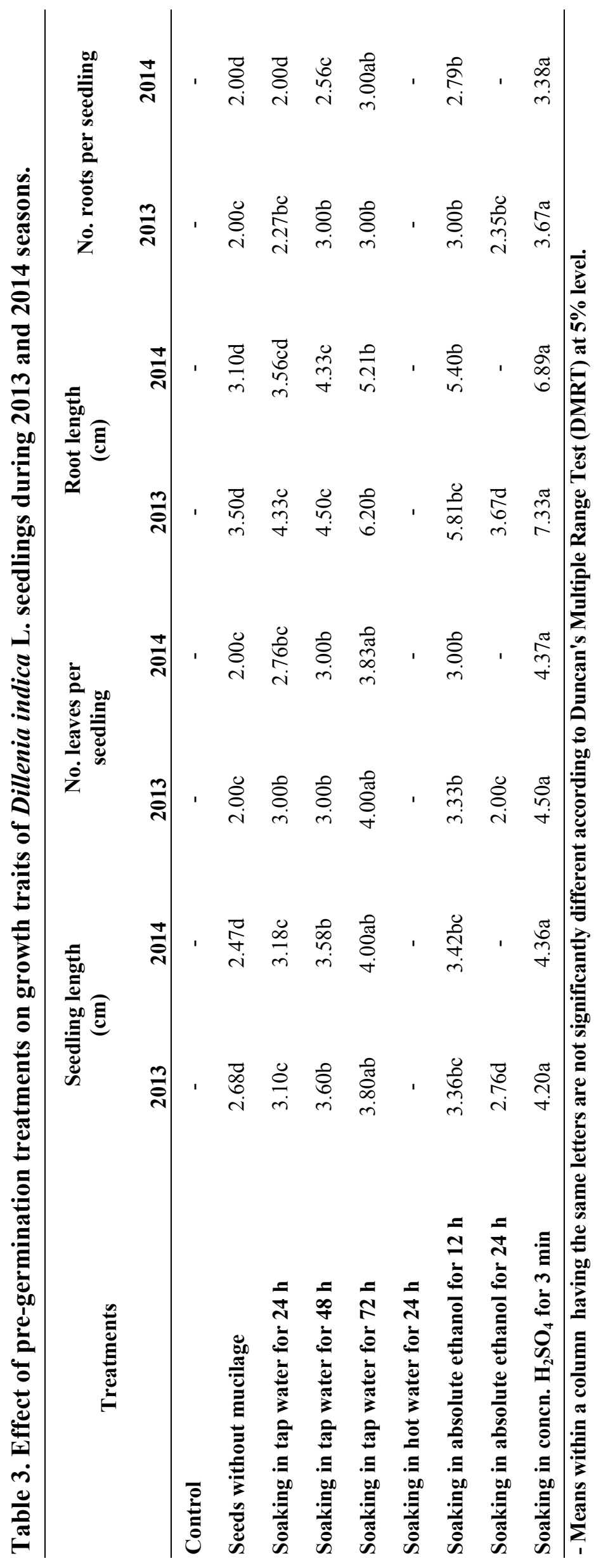


S.M. Shahin et al.

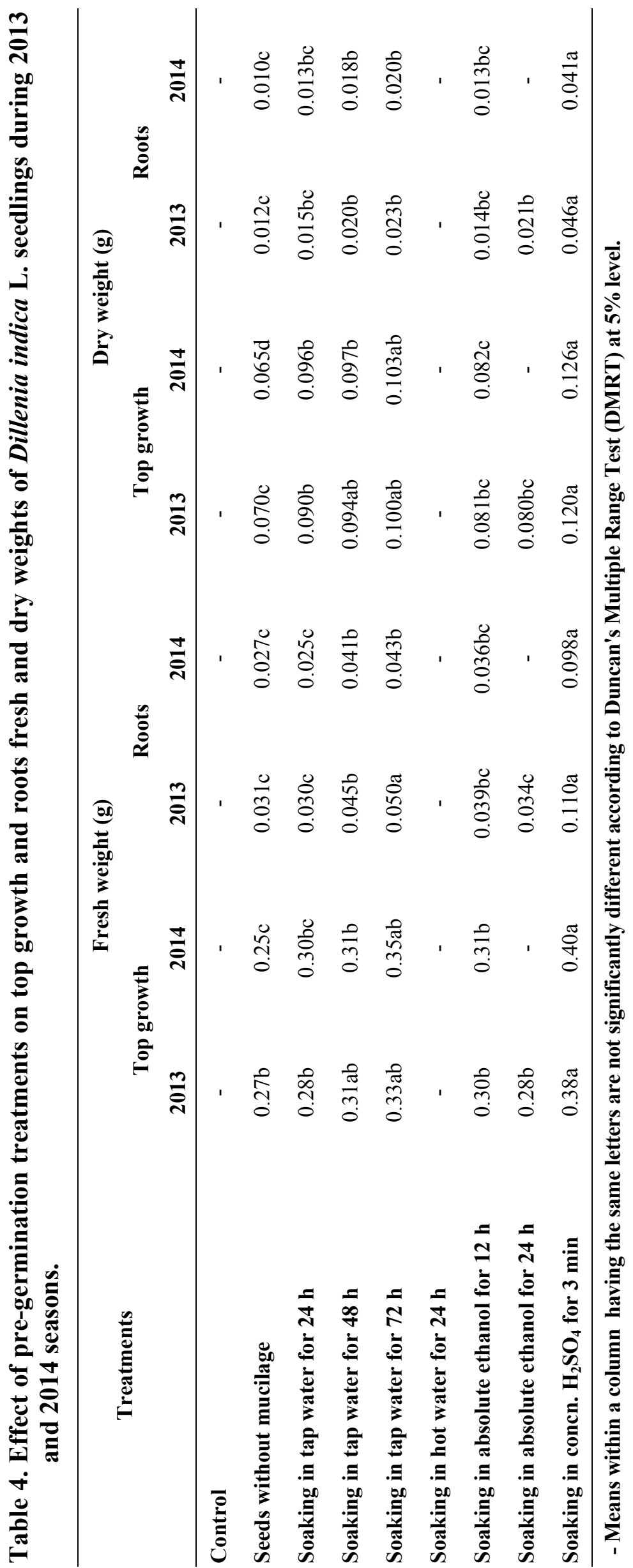


Scientific J. Flowers \& Ornamental Plants, 2(1):39-50 (2015)

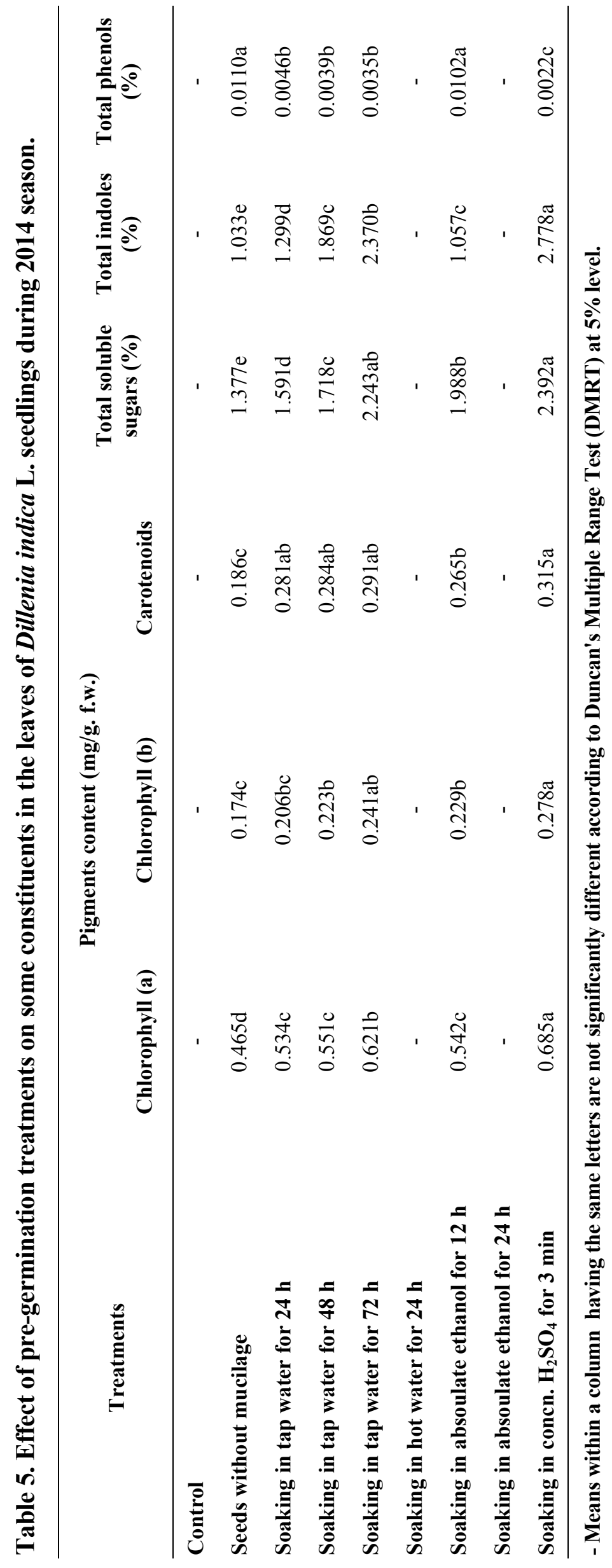




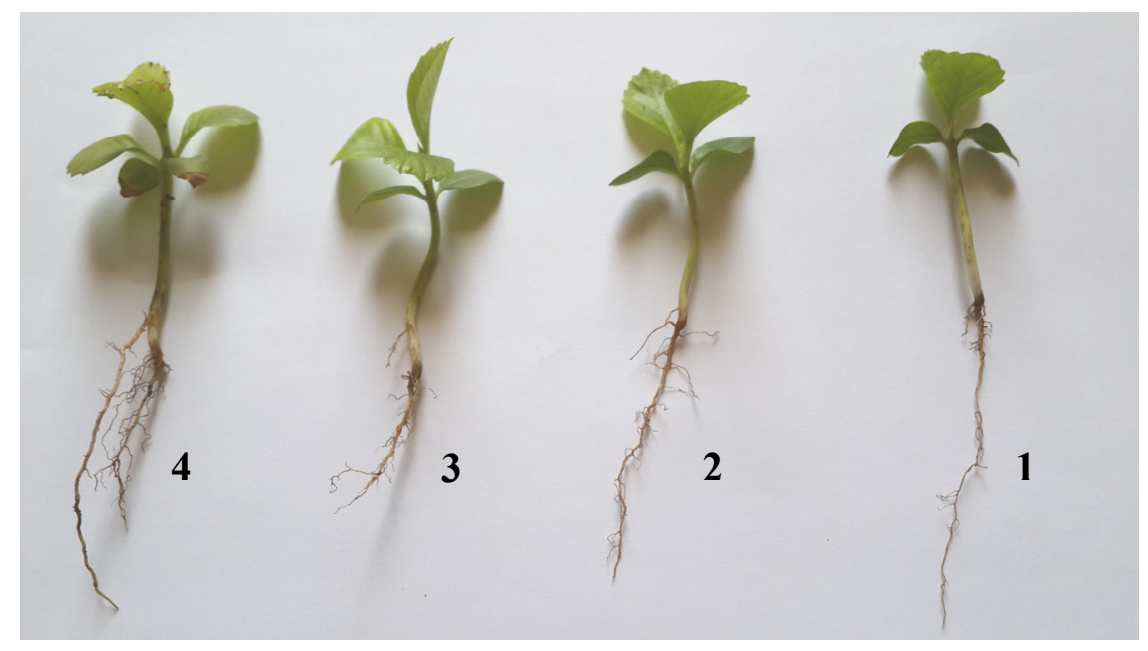

Fig. 4. Effect of acid treatment (4) and tap water for either $72 \mathrm{~h}$ (3) or $48 \mathrm{~h}$ (2) on seedling growth of Dillenia indica $\mathbf{L}$. compared to seedling raised from seeds without mucilage (1).

oxidase and might therefore be acting on plant activities through changes endogenous auxins activity (Kenneth, 1979).

From the foregone, it is concluded that soaking the seeds of Elephant apple (Dillenia indica L.) tree in either concentrated sulfuric acid $(98.5 \%)$ for $3 \mathrm{~min}$ or tap water for $72 \mathrm{~h}$ may be suitable methods for improving germination and seedling quality.

\section{REFERENCES}

Alam, M.B.; Chowdhury, N.S.; Mazumder, M.E.H. and Haque, M.E. (2011). Antimicrobial and toxicity study of different fractions of Dillenia indica L.: Bark extract. Inter. J. of Pharma. Sci. \& Res. (IJPSR), 2(4):860-866.

Alamgir, M. and Hossain, M.K. (2005). Effect of pre-sowing treatments on germination and initial seedling development of Albizia saman in the nursery. J. Forsetry Res., 16(3):200-204.

A.O.A.C. (1990). Association of Official Agricultural Chemists "Official Methods of Analysis of the Association of Official Agricultural Chemists". $15^{\text {th }}$ Ed., Arlington, Virginia 22201: 877-878.
Azad, M.S.; Biswas, R.K. and Abdul Matin, M. (2012). Seed germination of Albizia procera (Roxb) Benth. in Bangladesh: a basis for seed source variation and presowing treatment effect. Forestry Studies in China, 14(2):124-130.

Azad, M.S.; Paul, N.K. and Abdul Matin, M. (2010). Do pre-sowing treatments affect seed germination in Albizia richardiana and Lagerstroemia speciosa?. Frontiers of Agriculture in China, 4(2):181-184.

Bahar, N. (2011). Evaluation of pretreatment techniques to enhance seed germination of Acacia mangium Wild. Annals of Forestry, 19(2):221-226.

Bhardwaj, S.D.; Kumar, M.; Panwa, P. and Gautm, J. (2007). Effect of Pre-sowing seed treatments on germination behaviour of Albizia lebbeck seeds. Indian J. Forestry, 30(1):55-57.

Dubois, M.; Smith, F.; Illes, K.A.; Hamilton, J.K. and Rebers, P.A. (1956). Colorimetric mehod for determination of sugars and related substances. Ann. Chem., 28(3):350-356. 
Duncan, D.B. (1955). Multiple range and multiple F. Tests. Biometrics,11: 1- 24.

Gogoi, B.J.; Tsering, J. and Goswami, B.C. (2012). Antioxidant activity and phytochemical analysis of Dillenia indica L. fruit of sonitpur, Assam, India. Inter. J. Of Pharma. Sci. and Res. (IJPSR), 3(12):4909-4912.

Hartmann, H.T. and Kester, D.E. (1983). Plant Propagation: Principles and Practices. Printic-Hall Inc., Englewood Cliffs, New Jersey, USA.

Huxley, A.; Griffiths, M. and Levy, M. (1992). The New Royal Hort. Society Dictionary of Gardening. The Stockton Press Ltd., New York, 257 Park Avenue South, New York, N. Y. 10010, USA, Vol. 2, 747 pp.

Kenneth, V.T. (1979). Physiology of Plant Growth and Development. B. Willkins TaTa, McGraw-Hill Publishing Co. Ltd., New Delhi.

Khan, M.R. (2013). The effects of pretreatments on seed germination of Cassia auriculata L. and Cassia tora L. Advances in Plant Sciences, 26(1):253256.

Mead, R.; Curnow, R.N. and Harted, A.M. (1993). Statistical Methods in Agriculture and Experimental Biology. $2^{\text {nd }}$ Ed., Chapman \& Hall Ltd., London, 335 pp.

Moran, R. (1982). Formula for determination of chlorophyllous pigment extracted with $\mathrm{N}-\mathrm{N}$-dimethyl formamide. Plant Physiol, 69:1376-81.

Odetola, J.A. (1987). Studies on seed dormancy, viability and germination in ornamental palms. Principes, 31(1):2430.

Panigrahi, S.G. (1986). Seed dormancy of Rotala L., Ammannia L., Nesaca Kunth and Hionanthera Fernan and Diniz (Lytheraceae). Botanical J. of the Linnean Soci., 93:389-404.

Parvin, M.N.; Rahman, M.S.; Islam, M.S. and Rashid, M.A. (2009). Chemical and biological investigations of Dillenia indica L. Bangladesh J. Pharmacol., 4:122-125.

Pivetta, K.F.D.; Andrea, F.; Penariol, A.P.; daLuza, P.B.; deCastro A.; Patista, G.S. and Romani, G.N. (2013). Effect of temperature and scarification on seeds germination of Copernicia prunifera (Mill) H. E. Moore (Arecaceae). Acta Hort., 1000:367-372.

Rahman, M.S.; Shams-Ud-Doha, K.M. and Rahman, R. (2011). Antidiarrhoeal activity of the leaf and fruit extracts of Dillenia indica L. Inter. J. of Biosciences (IJB), 1(6):39-46.

SAS, Institute. (1994). SAS/STAT User's Guides Statistics. Vers. 6.04, $4^{\text {th }}$ Ed., SAS Institute Inc., Cary, N.C., USA.

Selvaraju, P. and Selvaraj, J. A. (1994). Effect of pre-sowing treatments on germination and vigour of seed in marigold (Tagetes erecta L.). Madras Agric. J., 81(9):469-497.

Shahin, S.M.; Ahmed, Magda A. and Noor El-Deen, T.M. (2014). Germination of hard to germinate tringle palm (Neodypsis decaryi Jumelle) seeds. J. Biol. Chem. \& Environ. Sci., 9(4):517530.

Singh, A. and Dhillon, G.P.S. (2007). Enhancing germination potential of three leguminous tree species through presowing seed treatments. Indian J. Forestry, 30(2):145-146.

Singha, A.K.; Bhattacharjee, B.; Ghosh, R.; De, U. and Maiti, D. (2013). Antibacterial, anti $\alpha$-glucosidase and antioxidant properties of Dillenia pentagyna Roxb. (Dilleniaceae). Asian J. of Pharma. \& Chemical Res., 6(4):173177.

Thapliyal, R.C.; Phartyal, S.S.; Baskin, J.M. and Baskin, C.C. (2008). Role of mucilage in germination of Dillenia indica (Dilleniaceae) seeds. Australian J. of Botany, 56:583-589. 


\section{S.M. Shahin et al.}

William, M.; Chichlilo, P.; Clifford, P.A. and Reynolds, M. (1965). Official Methods of Analysis of the Association of Official Agriculture Chemists, $10^{\text {th }}$ Ed., Washington D.C. 20044: 52-55.

\section{إستجابة بذور شجرة تفاحة الفيل (Dillenia indica L) لبعض معاملات ما قبل الإنبات

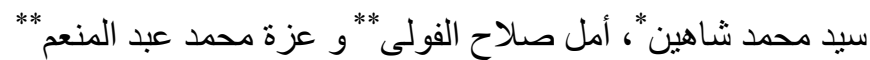

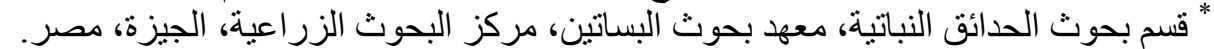

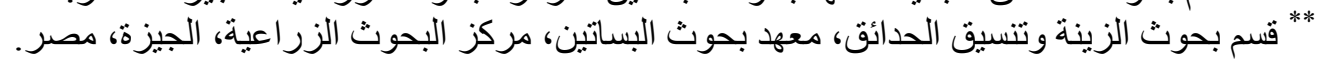

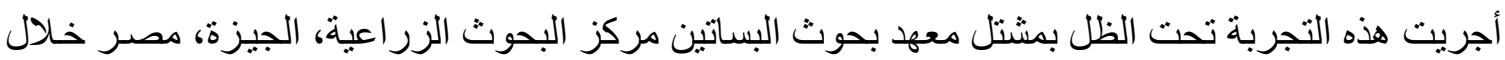

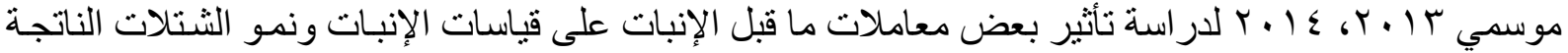

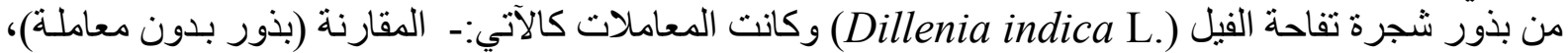

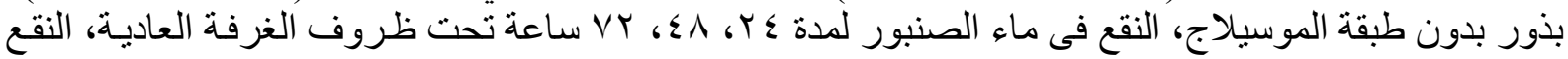

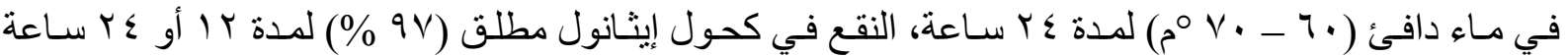

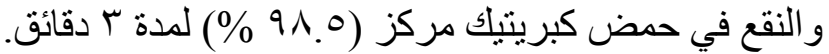

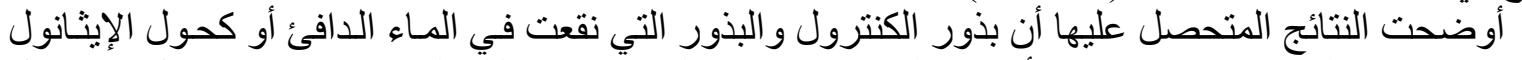

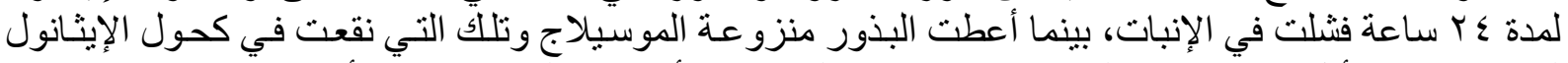

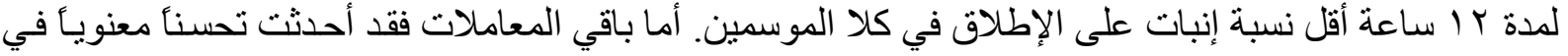

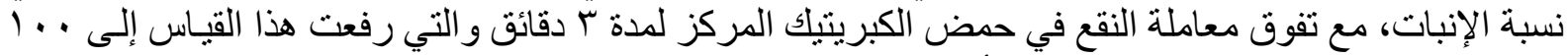

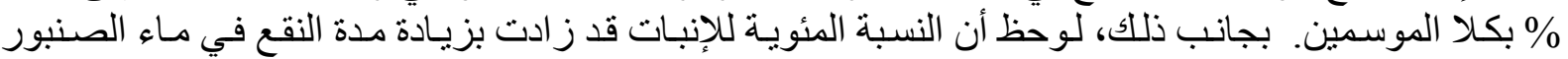

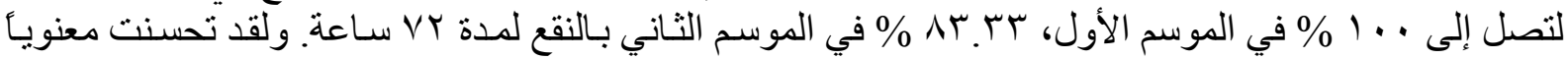

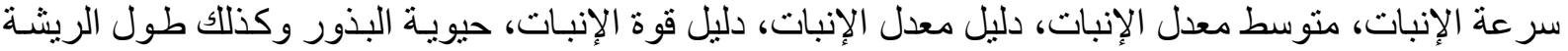

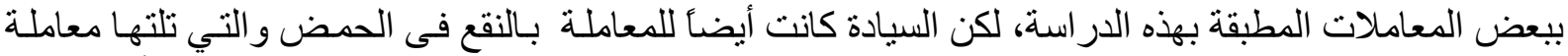

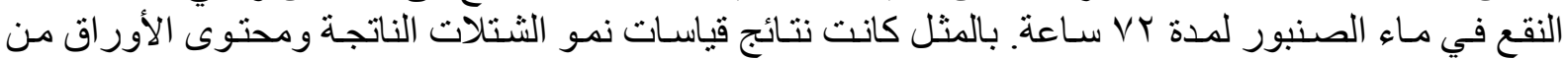

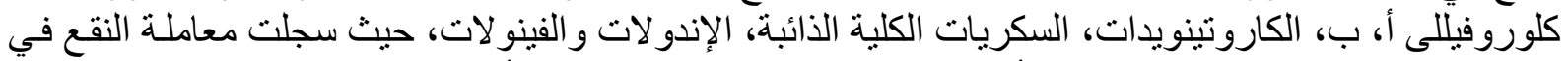

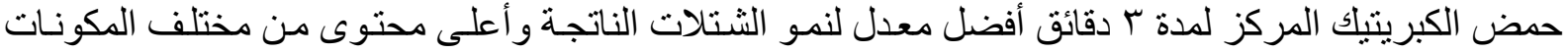

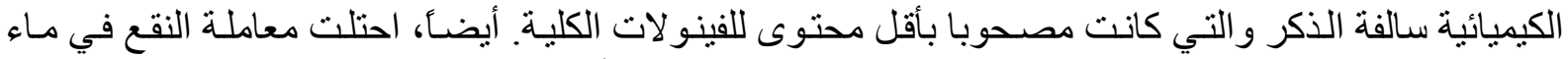

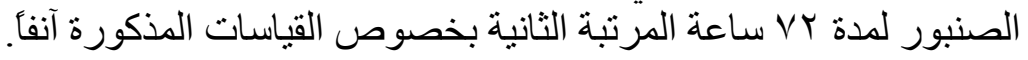

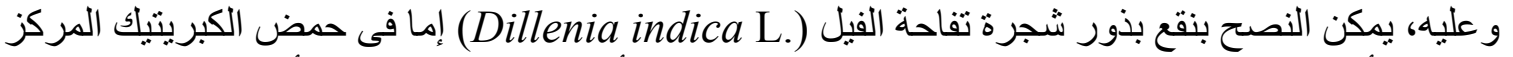

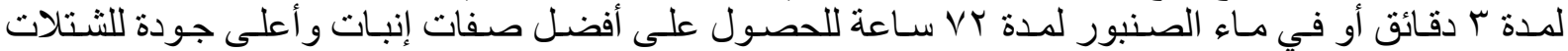

